\title{
LANDASAN PEMBENTUKAN SPASIAL KAWASAN TAMAN BUMI GLOBAL BATUR (BATUR GLOBAL GEOPARK, KINTAMANI, BANGLI, BALI)
}

\author{
Ni Putu Suda Nurjani \\ ${ }^{1}$ Program Studi Teknik Industri, Fakultas Teknik, Universitas Mahendradatta \\ Jl. Ken Arok No.12, Peguyangan, Denpasar, Bali 80115 \\ Email: suda.nurjani@gmail.com
}

\begin{abstract}
Abstrak - Kawasan Taman Bumi Global Batur (Batur Global Geopark) sebagai warisan Budaya Dunia merupakan sebuah kawasan yang terintegrasi yang terdiri atas 15 Desa dengan beragam potensi yang dimiliki. Potensi budaya, ekonomi, infrastruktur yang sangat menentukan keberlanjutan lingkungan di kawasan kaldera batur. Semenjak ditetapkan sebagai warisan budaya dunia oleh UNESCO pada tanggal 20 September 2012 di Portugal, kawasan ini belum mampu memberikan dampak positif bagi keberlanjutan lingkungan di sekitar kawasan geopark. Identifikasi potensi kawasan masih sangat minim, sehingga pemerataan dan pengembangan landasan spasial keruangan sangat sulit dilaksanakan. Penggambaran struktur ruang permukiman juga dapat dilihat dari sisi budaya lain seperti pada pelaksanaan ritual dan acara keagamaan. Kajian ini merupakan salah satu wujud identifikasi terhadap pembentukan struktur ruang spasial di kawasan kaldera batur. Pengumpulan data dengan pendekatan rasionalistik, observasi langsung ke objek studi, dan wawancara dengan masyarakat sekitar serta pemangku kebijakan, kemudian hasil data di analisis dengan teori terkait sehingga menghasilkan sebuah gambaran umum pembentukan struktur spasial ruang yang nantinya diharapkan bisa membantu pembangunan berkelanjutan di kawasan Kaldera Batur, Kintamani, Bangli.
\end{abstract}

\section{Kata kunci: Struktur Spasial, Geopark Batur, Permukiman}

\begin{abstract}
The area of Taman Bumi Global Batur (Batur Global Geopark) as the World Cultural heritage is an integrated area consisting of 15 villages with a variety of potential. Cultural potential, economic, infrastructure that determines the environmental sustainability in the caldera area of Batur. Since it was established as a world cultural heritage by UNESCO on September 20, 2012 in Portugal, the region has not been able to positively impact the environmental sustainability surrounding the Geopark area. Identifying the potential of the area is still minimal, so the distribution and development of spatial foundations of the spatial is difficult to implement. The depiction of the structure of the residential space can also be seen from other cultures such as ritual implementation and religious events. This study is one of identifying form of spatial structure of the area in the caldera. Data collection with observations directly to the object of study, and interviews with the surrounding community and policy stakeholders, then the results of data in the analysis with related theories that resulted in an overview of the establishment of spatial structure of space that is expected to help sustainable development in the caldera area of Batur, Kintamani, Bangli.
\end{abstract}

Keywords: Spatial structure, Geopark Batur, Settlement

\section{Pendahuluan}

Istilah spasial dalam ilmu arsitektur dipergunakan untuk menyebutkan jarak satu ruang ke ruang lainnya. Secara harfiah menurut Kamus Besar Bahasa Indonesia, spasial lebih berhubungan dengan spasi yang bermakna jarak, selingan bidang atau daerah di antara benda-benda. Adapun secara terminologis, Mulyati (1995) memberikan penjelasan bahwa "spasial" adalah ruang fisik yang terbentuk pada lingkungan permukiman, rumah tinggal dan bentuk bangunan yang terjadi karena faktor yang berkembang di lingkungan masyarakat.

Pembentukan suatu lingkungan pada dasarnya sangat ditentukan oleh berbagai 
faktor, diantaranya adalah budaya masyarakat setempat. Bagaimana individu berhubungan dengan keluarga dan lingkungan sekitarnya sudah tentu berbeda antara satu budaya dengan budaya lainnya, selanjutnya bagaimana ruang itu ditata dan dirancang sangat tergantung pada pandangan hidup masing-masing (Dansby, 1993: 137). Taman Bumi atau Geopark adalah pola pengembangan kawasan secara berkelanjutan yang memadukan secara serasi tiga keragaman yaitu geologi, hayati dan budaya. Tujuan pengelolaannya adalah untuk membangun dan mengembangkan ekonomi masyarakat setempat dengan berasaskan perlindungan atas ketiga keragaman geologi, hayati, budaya yang terdapat di dalam kawasan.

Bali melalui Taman Bumi Global Batur, Kintamani kini telah memasuki era pengembangan kawasan dengan pola Geopark. Pola pembangunan geopark menerapkan upaya-upaya perlindungan bersamaan dengan upaya pendidikan berbasis keragaman geologi yang ada beserta lingkungannya, dan penumbuhan ekonomi masyarakat setempat melalui geowisata dan wisata lainnya.

Keberlanjutan pembangunan Geopark batur tidak bisa terlepas dari potensi yang dimiliki kawasan sekitarnya. Bertitik tolak dari hal tersebut maka diperlukan identifikasi lebih lanjut mengenai isu-isu keberlanjutan yang ada di kawasan kaldera batur sehingga nantinya bisa diketahui potensi yang dimiliki serta bisa mendukung keberlajutan Geopark batur sebagai warisan budaya dunia.

\section{Pola Spasial Permukiman}

Pola spasial permukiman di desa menurut Wiriaatmadja (1981) adalah: (1) Pola permukiman dengan cara tersebar berjauhan satu sama lain; (2) Pola permukiman dengan cara berkumpul dalam sebuah kampung, memanjang 'mengikuti jalan lalu lintas'; (3) Pola permukiman dengan cara terkumpul dalam sebuah kampung/desa; (4) Berkumpul dan tersusun melingkar mengikuti jalan. Pola spasial permukiman di daerah pinggiran kota pada awalnya terbentuk dari aktivitas penduduk tani di desa, dengan ciri-ciri sebagian besar daerahnya adalah berupa lahan lahan pertanian yang mengarah pada pola spasial kota. Subroto (1997:46-48) menjelaskan perubahan spasial pinggiran kota sebagai berikut, a) Pola perubahan konsentris spasial (a pattern of spatial concentric), terbentuk oleh keberadaan akses jalan kelas 1 yang menghubungkan/memotong komunitas pinggiran kota. Pusat pertumbuhan ekonomi berada di sepanjang jalan utama, yang kemudian diikuti dengan kawasan peruntukan perumahan serta zona terluar adalah kawasan yang diperuntukkan untuk pertanian.

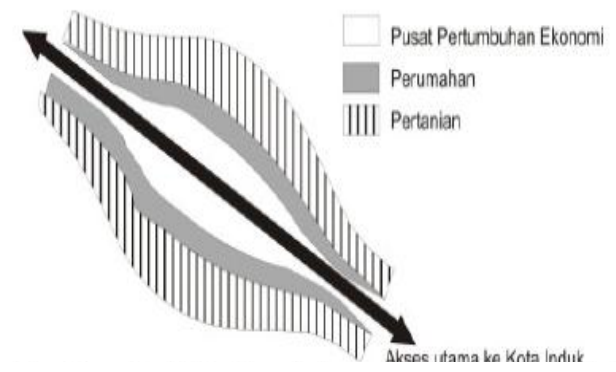

Gambar 1. Pola Perubahan Konsentris Spasial

Sumber: Subroto (1997)

Pola perubahan dispersi (pembubaran) spasial, terbentuk oleh adanya pembagian spasial secara merata dari suatu kelompok komunitas urban fringe, akibat dibangunnya jalan-jalan penghubung. Pola ini dapat disebut model katak lompat (leap frog model).

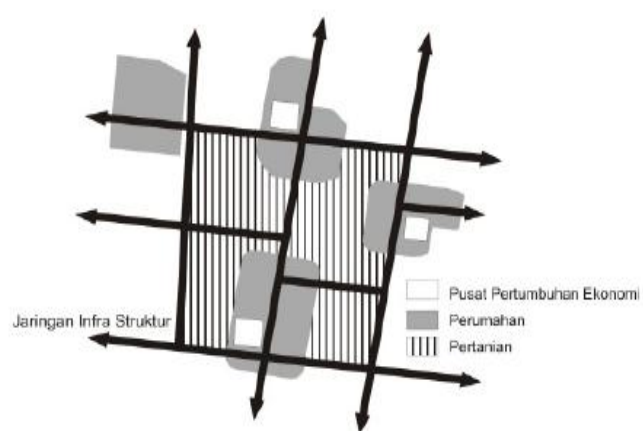

Gambar 2. Pola Perubahan Dispersi Spasial Sumber: Subroto (1997)

\section{Isu-Isu Pembangunan Berkelanjutan}

Pembangunan berkelanjutan adalah proses pembangunan (lahan, kota, bisnis, masyarakat, dsb) yang berprinsip "memenuhi kebutuhan sekarang tanpa mengorbankan 
pemenuhan kebutuhan generasi masa depan". Salah satu faktor yang harus dihadapi untuk mencapai pembangunan berkelanjutan adalah bagaimana memperbaiki kehancuran lingkungan tanpa mengorbankan kebutuhan pembangunan ekonomi dan keadilan sosial. Berdasarkan konsep pembangunan berkelanjutan tersebut, maka indikator pembangunan berkelanjutan tidak akan terlepas dari aspek-aspek tersebut diatas, yaitu aspek ekonomi, ekologi/lingkungan, sosial, politik, dan budaya. Sejalan dengan pemikiran tersebut, Djajadiningrat (2005) dalam buku Suistanable Future: Menggagas Warisan Peradaban bagi Anak Cucu, Seputar Pemikiran Surna Tjahja Djajadiningrat, menyatakan bahwa dalam pembangunan yang berkelanjutan terdapat aspek keberlanjutan yang perlu diperhatikan, yaitu: 1 . Keberlanjutan Ekologis, 2. Keberlanjutan di Bidang Ekonomi, 3. Keberlanjutan Sosial dan Budaya, 4. Keberlanjutan Politik, 5. Keberlanjutan Pertahanan Keamanan. Prof. Otto Soemarwoto dalam Sutisna (2006), mengajukan enam tolok ukur pembangunan berkelanjutan secara sederhana yang dapat digunakan baik untuk pemerintah pusat maupun di daerah untuk menilai keberhasilan seorang Kepala Pemerintahan dalam pelaksanaan proses pembangunan berkelanjutan. Keenam tolok ukur itu meliputi: pro lingkungan hidup, pro rakyat miskin, pro kesetaraan jender, pro penciptaan lapangan kerja, pro dengan bentuk negara kesatuan RI dan, harus anti korupsi, kolusi serta nepotisme.

\section{Taman Bumi (Geopark)}

Pengertian Geopark dapat dipahami melalui arti, fungsi dan implementasinya sebagai komponen yang berkaitan dengan alam dan kehidupan di bumi. Oleh sebab itu konsep Geopark memiliki tiga pengertian dasar, yaitu:

Merupakan kawasan yang memiliki makna sebagai suatu warisan geologi (sehingga perlu dilestarikan), sekaligus sebagai tempat mengaplikasikan strategi pengembangan ekonomi berkelanjutan yang dilakukan melalui struktur manajemen yang baik dan realistis.

Geopark berimplementasi memberi peluang bagi penciptaan lapangan pekerjaan untuk masyarakat setempat dalam hal memperoleh keuntungan ekonomi secara nyata (biasanya melalui kegiatan pariwisata berkelanjutan).

Di dalam kerangka Geopark, objek warisan geologi dan pengetahuan geologi berbagi dengan masyarakat umum. Unsur geologi dan bentangalam yang ada berhubungan dengan aspek lingkungan alam dan budaya.

Pengertian Geopark-pun dapat dipahami melalui beberapa aspek seperti: 1 . Sebagai suatu kawasan; Geopark merupakan sebuah kawasan yang berisi aneka jenis unsur geologi yang memiliki makna dan fungsi sebagai warisan alam. Geopark harus memiliki batas yang tegas dan nyata. Luas permukaan Geopark-pun harus cukup, dalam artian dapat mendukung penerapan kegiatan rencana aksi pengembangannya. 2. Sebagai sarana pengenalan warisan bumi; Geopark mengandung sejumlah situs geologi (geosite) yang memiliki makna dari sisi ilmu pengetahuan, kelangkaan, keindahan (estetika), dan pendidikan. Kegiatan di dalam Geopark tidak terbatas pada aspek geologi saja, tetapi juga aspek lain seperti arkeologi, ekologi, sejarah, dan budaya. 3. Sebagai kawasan lindung warisan bumi. Situs geologi penyusun Geopark adalah bagian dari warisan bumi. Berdasarkan arti, fungsi dan peluang pemanfaatannya, keberadaan dan kelestarian situs-situs itu perlu dijaga dan dilindungi. 4. Sebagai tempat pengembangan geowisata; Objek-objek warisan bumi di dalam Geopark berpeluang menciptakan nilai ekonomi. Pengembangan ekonomi lokal melalui kegiatan pariwisata berbasis alam (geologi) atau geowisata merupakan salah satu pilihan. Penyelenggaraan kegiatan pariwisata Geopark secara berkelanjutan dimaknai sebagai kegiatan dan upaya penyeimbangan antara pembangunan ekonomi dengan usaha konservasi. 5. Sebagai sarana kerjasama yang efektif dan efisien dengan masyarakat lokal; Pengembangan Geopark di suatu daerah akan 
berdampak langsung kepada manusia yang tinggal di dalam dan di sekitar kawasan. Konsep Geopark memperbolehkan masyarakat untuk tetap tinggal di dalam kawasan, yaitu dalam rangka menghubungkan kembali nilai-nilai warisan bumi kepada mereka. 6. Sebagai tempat implementasi aneka ilmu pengetahuan dan teknologi; Di dalam kegiatan melindungi objek-objek warisan alam dari kerusakan atau penurunan mutu lingkungan, kawasan Geopark menjadi tempat uji coba metoda perlindungan yang diberlakukan. Selain itu, kawasan Geopark juga terbuka sepenuhnya untuk berbagai kegiatan kajian dan penelitian aneka ilmu pengetahuan dan teknologi tepat-guna.

\section{Tujuan}

Adapun tujuan dari penelitian ini adalah untuk mengidentifikasi pola spasial kawasan Taman Bumi Global Batur (Batur Global Geopark) dan isu-isu yang berkembang di sekitar kawasan sehingga bisa dilihat potensipotensi di sekitar kaldera batur, yang mana nantinya diharapkan mampu mendukung pembangunan berkelanjutan di Taman Bumi Global Batur (Batur Global Geopark).

\section{Metode Penelitian}

Lokasi penelitian berada di Kecamatan Kintamani, Kabupaten Bangli. Secara makro penelitian ini mengamati pola spasial Kawasan Taman Bumi Global Geopark Batur berdasar pada batas-batas administratif dan secara mikro mengamati lingkungan permukiman penduduk dan isu-isu pembangunan yang berkembang sejak ditetapkannya Batur sebagai kawasan Geopark oleh UNESCO. Peneliti menggunakan pendekatan rasionalistik. Dalam Muhadjir N. (1992:88) dijelaskan bahwa pendekatan rasionalistik menuntut sifat holistik, obyek diteliti tanpa dilepaskan dari konteksnya. Instrumen utama yang digunakan dalam penelitian ini adalah peneliti sendiri dan dibantu oleh rekan yang mendukung proses penelitian, seperti wawancara, scanning obyek maupun dalam menstrukturkan data yang diperoleh. Penelitian bersifat deskriptif-eksplanatif yang bertujuan untuk mendapatkan gambaran tentang spasial permukiman. Analisis data dilakukan secara semiotik, yaitu mengaitkan antara faktor pembentukan spasial permukiman dan kehidupan sosio-kultural penduduk, sehingga dapat dimaknai unsur tanda (spasial permukiman) dan unsur penanda (kehidupan sosio-kultural) yang diharapkan menjadi jawaban pertanyaan penelitian.

\section{Gambaran Umum Kawasan Geopark Batur}

Secara geografis Kecamatan Kintamani terletak di sebelah Timur Laut Kota Denpasar dengan jarak $\pm 67 \mathrm{~km}$, atau sebelah Utara Kota Bangli dengan jarak $\pm 27 \mathrm{~km}$. Secara administrasi kawasan perencanaan meliputi 15 desa. Selengkapnya dapat dilihat pada tabel di bawah ini.

Tabel 1.

Jumlah Desa Pakraman di Kawasan geopark Batur Sumber: BPS Provinsi Bali 2010

\begin{tabular}{|l|l|c|c|c|}
\hline No & \multicolumn{1}{|c|}{$\begin{array}{c}\text { Desa / } \\
\text { Kelurahan }\end{array}$} & $\begin{array}{c}\text { Luas } \\
\text { Wilayah } \\
\text { (Km2) }\end{array}$ & $\begin{array}{c}\text { Jumlah } \\
\text { Dusun }\end{array}$ & $\begin{array}{c}\text { Jumlah } \\
\text { Desa } \\
\text { Pakraman }\end{array}$ \\
\hline 1 & Sukawana & 33,61 & 9 & 3 \\
\hline 2 & Terunyan & 19,63 & 5 & 1 \\
\hline 3 & Pinggan & 16,53 & 1 & 1 \\
\hline 4 & Kintamani & 15,13 & 9 & 3 \\
\hline 5 & Songan B & 11,88 & 18 & 1 \\
\hline 6 & Songan A & 17,01 & 15 & 1 \\
\hline 7 & Batur Selatan & 13,86 & 11 & 1 \\
\hline 8 & Batur Tengah & 4,74 & 8 & 1 \\
\hline 9 & Batur Utara & 3,36 & 5 & 1 \\
\hline 10 & Kedisan & 11,75 & 1 & 1 \\
\hline 11 & Buahan & 14,23 & 4 & 2 \\
\hline 12 & Suter & 12,56 & 5 & 1 \\
\hline 13 & Abangbatudinding & 14,33 & 6 & 1 \\
\hline 14 & Abangsongan & 7,08 & 6 & 1 \\
\hline 15 & Blandingan & 6,00 & 1 & 1 \\
\hline & Jumlah & 201,70 & $\mathbf{1 0 4}$ & \\
\hline
\end{tabular}

Luas wilayah kintamani adalah 366,92 $\mathrm{Km}^{2}$ dengan jumlah KK (Kepala Keluarga) sebanyak 2.328 KK. Penduduk laki-laki berjumlah 46.386 orang, perempuan berjumlah 46.540 orang sehingga jumlah total penduduk kintamani adalah 92.926 Jiwa. Kepadatan penduduk di Kecamatan Kintamani 253/ $\mathrm{Km}^{2}$. Laju pertumbuhan penduduk di kintamani pada tahun 1980-1990 (1,21\%), 1990-2000 (1,42\%), 2000-2010 (1.16\%).

Sumber Ekonomi penduduk Kintamani sebagian besar berasal dari sector pertanian. Ini dibuktikan dengan jumlah petani yang ada 
di kintamani sebanyak 608 orang dengan luas area produktif $41 \mathrm{Ha}$ dengan luas produksi 6.505 Ton. Hasil pertanian utama adalah jagung dengan luas panen $1.039 \mathrm{Ha}$ dengan jumlah produksi 46.370,82 Ton, Kubis dengan luas panen $589 \mathrm{Ha}$ dengan jumlah produksi 189.999 Ton, Sawi; Luas panen 93 Ha dengan jumlah produksi 9.858 Ton (Sumber: Bangli dalam angka 2013).

\section{Potensi Kawasan Geopark}

\section{a) Potensi geologi}

Kawasan Kaldera Geopark Batur, memiliki warisan geologi yaitu kaldera, kawah, lava, goa, dan mata air panas. Kaldera yang ada yaitu Kaldera Luar/Kaldera Catur dan Kaldera Dalam/Kaldera Batur. Kaldera Catur dengan ukuran $13,8 \mathrm{~km} . \times 10 \mathrm{~km}$., dan ketinggian antara $1.267-2.152 \mathrm{~m}$., menjulang sekitar 500 m., dari dasar kaldera, serta Kaldera Batur yang memiliki garis tengah sekitar 7,5 km., terletak 300 m., di bawah Kaldera Catur. Kaldera ini menjadi panorama yang sangat indah jika dilihat dari Penelokan. Kawah, lava, goa dengan lorong lava, dan mata air panas merupakan warisan geologi yang berpotensi untuk pengembangan pariwisata, edukasi, serta konservasi.

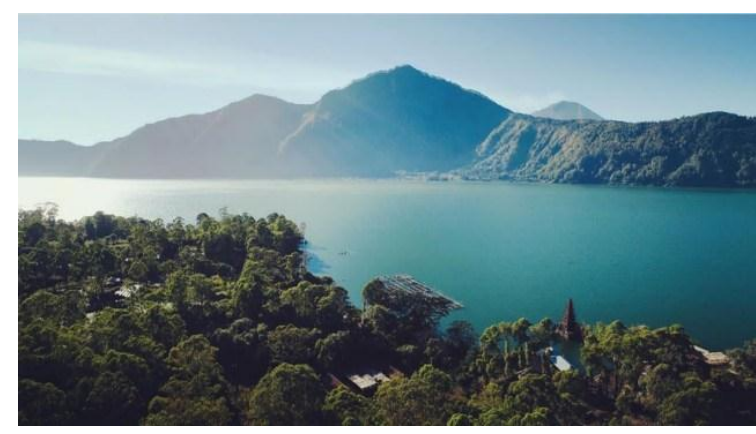

Gambar 3. Kawasan Kaldera Batur, Kintamani, Bangli

Sumber:https://kumparan.com/kanalbali/jelangvalidasi-unesco-kelembagaan-geopark-baturperlu-diperkuat-1rgO5194lkP/full

Potensi geologi yang dimiliki oleh Kecamatan Kintamani berpotensi dikembangkan untuk edukasi dan pariwisata. Kaldera Batur terdiri atas berbagai lapisan vulkanik yang terbagi atas dua bentuk kaldera hasil erupsi, Catur (13 x $10 \mathrm{~km} 2$ ) dan Batur (diameter 7,5 km) dibentuk di tengah-tengah. Tinggi dari lingkaran kaldera bervariasi dari $1.267 \mathrm{~m}$ sampai $2.152 \mathrm{~m}$ asl. Sisi timur kaldera ditempati oleh danau. Puncak Batur yang aktif $(1.717 \mathrm{~m})$ terletak di $8^{\circ} 14^{\prime} 30^{\prime \prime}$ selatan dan $115^{\circ} 22^{\prime} 30^{\prime \prime}$ timur yang berada di pusat kaldera. Menurut Kemmerling (1918), Gunung Sukawana dan Gunung Abang (2.152 m) merupakan sisa-sisa vulkanik. Diduga kalau Gunung Batur purba (pre-caldera) lebih tinggi dari Gunung Agung (3.142 m), dan area kaldera yang terbentuk saat ini dibentuk dari stratovolcavo tua yang gugur.

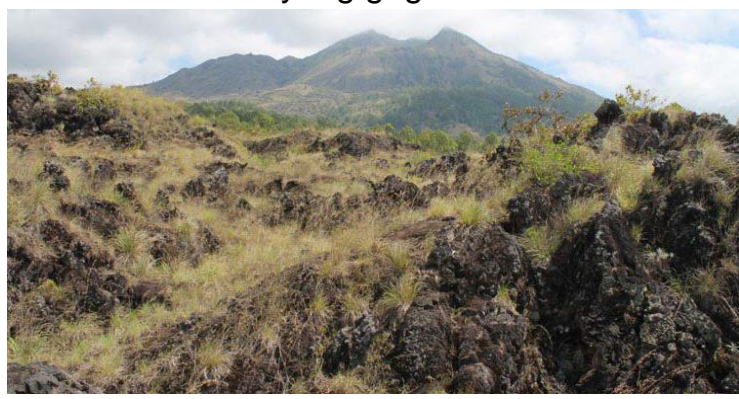

Gambar 4. Potensi Geologi yang Dimiliki oleh Kaldera Batur

Sumber:

https://www.airmagz.com/18905/kaldera-batursitus-warisan-geologis-dunia-yangmengagumkan.html

\section{b) Potensi Pariwisata}

Berdasarkan SK Bupati Bangli No. 15 Tahun 1995, Kawasan di Dalam Kaldera Geopark Batur memiliki beberapa objek wisata alam unggulan yaitu Toyabungkah, Penelokan, Penulisan, Terunyan dan Kintamani. Kawasan ini sangat terkenal bagi wisatawan baik wisatawan nusantara maupun mancanegara. Hal ini disebabkan karena di dalam kawasan terdapat beberapa potensi alamiah yang menawan dan menakjubkan yaitu perpaduan antara alam pegunungan (Gunung Batur dan Gunung Abang) dengan kaldera serta danau (Danau Batur) yang berada di dalam kaldera. Selain itu, Kawasan di Dalam Kaldera Geopark Batur memiliki sejumlah keunikan adat istiadat masyarakat lokal yang terlihat dari berbagai aktivitas spiritual yang ditunjukkan dari adanya Pura-Pura bersejarah dan pemukiman tradisional. Adapun objek wisata alam di kawasan ini adalah sebagai berikut: 
Tabel 2.

Objek Wisata Alam di Kawasan Kaldera Batur

\begin{tabular}{|l|l|l|}
\hline No & \multicolumn{1}{|c|}{ Objek Wisata } & \multicolumn{1}{|c|}{ Daya Tarik Wisata Alam } \\
\hline 1 & Penelokan & $\begin{array}{l}\text { Panorama yang indah } \\
\text { kearah danau batur, gunung } \\
\text { batur,dan desa-desa } \\
\text { disekitarnya. }\end{array}$ \\
\hline 2 & Kintamani & $\begin{array}{l}\text { Panorama Gunung Batur } \\
\text { yang Indah yang berhawa } \\
\text { sejuk }\end{array}$ \\
\hline 3 & Bukit penulisan & $\begin{array}{l}\text { Peninggalan bersejarah } \\
\text { seperti patung/arca, Pura } \\
\text { Bukit Penulisan }\end{array}$ \\
\hline 4 & Abang songan & $\begin{array}{l}\text { Pemandangan Gunung } \\
\text { Batur dan desa-desa } \\
\text { disekitarnya }\end{array}$ \\
\hline 5 & Kedisan & $\begin{array}{l}\text { Panorama indah gunung } \\
\text { batur,desa tradisional dan } \\
\text { agro wisata }\end{array}$ \\
\hline 6 & Toyabungkah & $\begin{array}{l}\text { Sumber air panas dan agro } \\
\text { wisata }\end{array}$ \\
\hline 7 & Buahan & $\begin{array}{l}\text { Pemandangan indah danau } \\
\text { batur \& agro wisata }\end{array}$ \\
\hline 8 & Terunyan & $\begin{array}{l}\text { Desa bali Kuno,adat istiadat } \\
\text { serta budaya yang unik (tata } \\
\text { cara pnguburan mayat) }\end{array}$ \\
\hline 9 & Danau batur & $\begin{array}{l}\text { Panorama gunung abang, } \\
\text { gunung batur serta agro } \\
\text { wisata yang indah }\end{array}$ \\
\hline 10 & Gunung Batur & $\begin{array}{l}\text { Potensi kawah \& lubang } \\
\text { kepundan, lava, panorama } \\
\text { indah, } \\
\text { edukasi,penelitian,pendakian } \\
\text { (pecinta alam) }\end{array}$ \\
\hline
\end{tabular}

Dilihat dari sudut pandang biodiversity, kawasan kintamani juga memiliki beberapa potensi antara lain: Kopi arabika khas kintamani, jeruk kintamani dan anjing kintamani. Anjing kintamani yang merupakan anjing ras asli kawasan. Secara fenotipe anjing Kintamani mudah dikenal, dapat dibandingkan dengan anjing-anjing lokal yang ada, atau anjing hasil persilangan antara ras yang sama maupun persilangan lainnya

\section{c) Infrastruktur}

Jaringan jalan di kawasan yang berfungsi sebagai jalan kolektor primer kondisinya cukup baik, sedangkan jaringan jalan lainnya yang berfungsi sebagai jalan lokal kondisinya sebagian telah beraspal dan sebagian lagi masih berupa jalan tanah. Terdapat beberapa desa yang selain dihubungkan melalui jalur darat juga dihubungkan melalui angkutan danau. Desadesa ini antara lain Desa Kedisan dan Terunyan. Desa Kedisan memiliki terminal angkutan danau yang melayani trayek Kedisan-Terunyan dan Kedisan-Toyabungkah. Sedangkan di Desa Terunyan, terdapat angkutan danau yang melayani trayek Terunyan-Kuburan, Terunyan-Kedisan dan Terunyan-Toyabungkah. Akan tetapi angkutan transportasi di Desa Terunyan ini tidak beroperasi secara maksimal, hanya angkutan menuju kuburan Terunyan saja yang beroperasi efektif. Hal ini disebabkan Desa Terunyan saat ini dapat diakses melalui jalur darat. Jaringan listrik juga sudah mencapai seluruh kawasan kintamani, hanya saja untuk kebutuhan air bersih, penduduk lokal lebih banyak memanfaatkan sistem sumur Bor. Peta Infrastruktur kawasan Kintamani bisa dilihat pada Gambar dibawah ini:

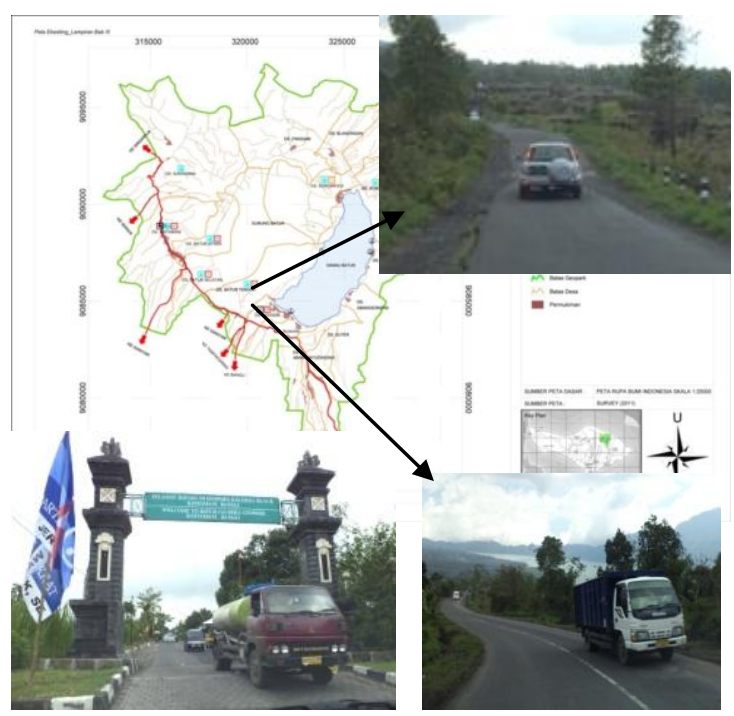

Gambar 5. Kondisi Infrastruktur Kawasan Kaldera Batur

\section{Isu Pembangunan Berkelanjutan di Kawasan Geopark Batur}

Pada tahun 90-an wilayah Kintamani merupakan salah satu objek wisata favorit di pulau Bali. Namun dalam perjalanannya, pengembangan kawasan wisata ini tidak berjalan dengan baik. Kurangnya sosialisasi kepariwisataan terhadap masyarakat lokal menjadi salah satu penyebab kesemrawutan ruang di sepanjang kawasan menuju kaldera Batur. Masyarakat yang berjualan di area objek wisata penelokan, pura batur, maupun toya bungkah, cenderung menawarkan barang 
dagangan yang bersifat memaksa. Hal ini berdampak sangat negatif bagi citra pariwisata Kintamani. Masyarakat Desa Terunyan juga sangat sering mempermainkan penumpang pada waktu akan menyebrang di kawasan dermaga. Isu bensin habis di tengah danau sudah menjadi hal umum di kalangan pewisata. Hal ini membuat orang-orang mulai enggan datang berkunjung ke kintamani. Isu Global Mengenai Politik, Keamanan,
Kesehatan, dan Demografi di Kintamani

Masalah keamanan ternyata telah menciptakan citra kurang menguntungkan bagi industri pariwisata global, dimana keselamatan wisatawan yang menjadi faktor utama telah terusik akibat aksi bom di destinasi maupun fasilitas pariwisata (hotel dan pesawat terbang) serta didorong dengan adanya pandangan bahwa saat ini tidak ada destinasi yang aman untuk berwisata. Masalah kesehatan global juga menjadi perhatian serius dalam pengembangan kepariwisataan dunia. Penyebaran AIDS, Meningitis, Cholera, Demam Berdarah dan Tubercolosis yang semakin tinggi berakibat kurang menguntungkan bagi pergerakan wisatawan dunia. Antisipasi dalam mencegah penyebaran penyakit mematikan tersebut serta keterbukaan informasi masing-masing negara merupakan faktor penting dalam menciptakan daya tarik bagi calon wisatawan untuk kembali melakukan perjalanan wisata ke negaranegara yang mengalami pandemi tersebut.

Dari sisi demografis, kecenderungan peningkatan angka jumlah penduduk, secara otomatis akan memicu meningkatnya kebutuhan perekonomian dan kebutuhan akan lahan permukiman, kebutuhan prasarana dasar seperti listrik dan air bersih serta fasilitas-fasilitas umum seperti fasilitas pendidikan, kesehatan, dan perekonomian. Permasalahan galian $\mathrm{C}$ yang berada di Desa Songan merupakan salah satu permasalahan yang terjadi akibat keinginan pemenuhan kebutuhan ekonomi akibat penambahan jumlah penduduk.

\section{Permasalahan Pasca Penetapan Kawasan Kaldera Batur Sebagai Salah Satu Global Geopark Network}

Pasca penetapan batur sebagai salah satu member GGN (Global Geopark Network) 20 september 2012, belum membawa perubahan berarti bagi kehidupan masyarakat di sekitar kawasan geopark. Adanya akomodasi wisata di sekitar kawasan geopark, tumbuh dan berkembang tanpa penyerapan tenaga kerja lokal ataupun kontribusi ke desa, terkecuali Desa Trunyan. Hal ini menyebabkan kesadaran masyarakat untuk mendukung program geopark masih sangat rendah. Pemenuhan kebutuhan ekonomi masih menjadi prioritas utama masyarakat. Kawasan yang seharusnya menjadi Konservasi Geologi, banyak yang beralih fungsi menjadi perkebunan guna pemenuhan kebutuhan ekonomi.

Aktivitas Galian C adalah tantangan utama untuk menjaga keberlanjutan kawasan Geopark Batur. Besarnya kontribusi yang diperoleh Desa Adat Songan maupun masyarakat sekitar Geopark Batur dari aktivitas galian $\mathrm{C}$, mengakibatkan permasalahan ini tidak pernah menemui titik akhir. Imbauan pelestarian lingkungan tanpa ada solusi yang jelas sebagai pengganti kesejahteraan, membuat masyarakat yang pro galian C jumlahnya semakin bertambah. Kondisi ini membuat struktur ruang yang terbentuk di sekitar kaldera Batur mulai mengalami perubahan fungsi.

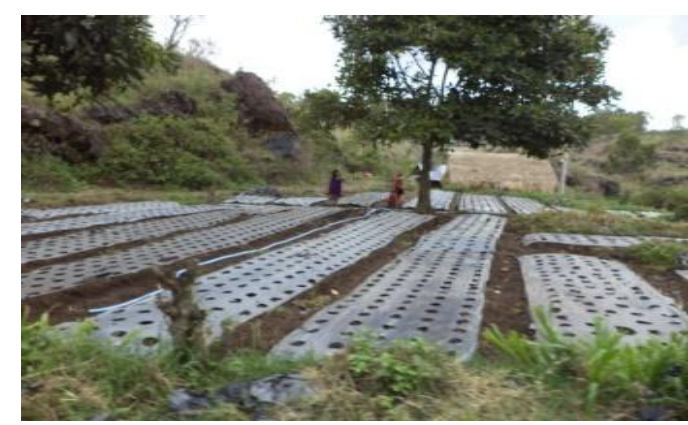

Gambar 7. Alih Fungsi Lahan di Kawasan Kaldera Batur

Perubahan tatanan spasial ruang, membuat membuat status kawasan ini mulai dipertimbangkan kembali. Pemanfaatan kawasan konservasi batuan geologi sebagai 
area bercocok tanam oleh masyarakat membuat beberapa batuan menjadi hilang. Permasalahan retribusi yang menjadi konflik yang belum menemukan titik temu.

\section{Landasan Pembentukan Spatial Kawasan Geopark Batur}

Menurut Subroto (1997:46-48) Pola perubahan dispersi (pembubaran)spasial, terbentuk oleh adanya pembagian spasial secara merata dari suatu kelompok komunitas urban fringe, akibat dibangunnya jalan-jalan penghubung. Hal ini juga berlaku di kawasan geopark Batur. Kondisi kelerengan rata-rata antara $30-70 \%$ pada Kawasan di dalam Kaldera Geopark Batur menyebabkan tidak banyak lahan yang dapat diusahakan sebagai lahan permukiman dan kawasan terbangun. Untuk masyarakat yang tinggal di wilayah yang jauh dari jaringan jalan akan kesulitan untuk melakukan mobilitas. Permukiman cenderung tumbuh dekat dengan jaringan jalan. Kondisi fisik dasar Kawasan di Dalam Kaldera Geopark Batur sangat mendukung kegiatan perkebunan dan pertanian lahan kering (sayursayuran dan buah-buahan) untuk berkembang. Sehingga pada Kawasan di Dalam Kaldera Geopark Batur sangat mudah ditemui lahan yang dimanfaatkan untuk perkebunan dan pertanian lahan kering seperti kubis dan tomat.

Kawasan tidak terbangun pada Kawasan di Dalam Kaldera Geopark Batur umumnya meliputi, kawasan geologi, kawasan danau, serta kawasan alam lindung lainnya. Kesemuanya dapat dikembangkan untuk edukasi dan kepariwisataan. Berdasarkan analisa potensi fisik dan non fisik kawasan secara umum landasan pembentukan spatial kawasan geopark batur adalah sebagai berikut. Pertama, adalah keberadaan permukiman tradisional Desa Trunyan dengan keunikan budaya dan adat istiadatnya memberi pengaruh besar terhadap perkembangan pariwisata di Kecamatan Kintamani.

Lima belas desa adat yang merupakan pendukung kawasan geopark memiliki daya tarik wisata alam yang cukup tinggi dengan keunggulan potensi agrowisata pada masing- masing kawasan. Seluruh kawasan mempunyai batas yang jelas yang merupakan salah satu syarat diterimanya batur menjadi anggota Global Geopark Network.
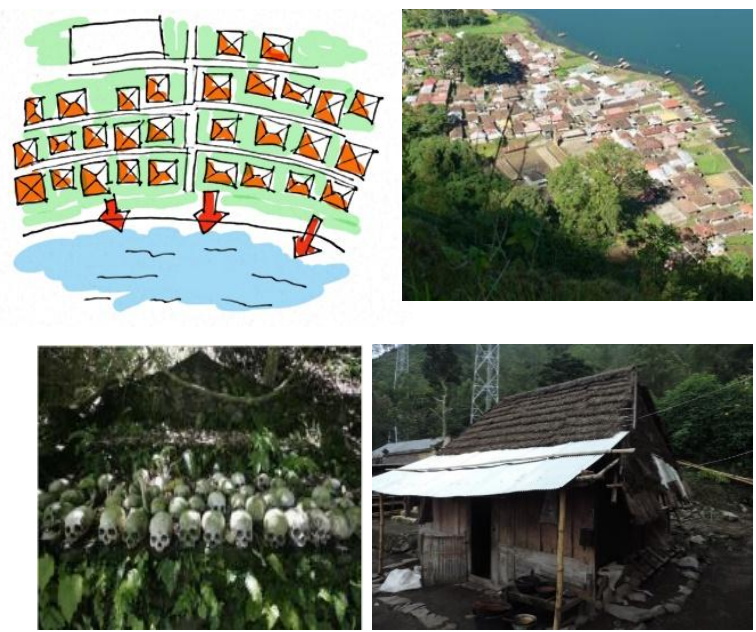

Gambar 6. Permukiman Desa Trunyan sebagai salah satu potensi Kaldera Batur

Sumber:https://andypriawan.wordpress.com/201 5/06/08/163/

Kedua, dilihat berdasarkan potensi geologi yang dimiliki oleh kaldera Batur. Berdasarkan aspek Geologi, Kabupaten Bangli secara umum termasuk dalam Qhvb di seputaran puncak Gunung Batur, Qvbb di seputaran bagian bawah Gunung Batur, dan Qpbb di sebagian besar wilayah Kabupaten Bangli. Formasi ini pada bagian permukaan didominasi oleh tufa pasiran dan di beberapa tempat dijumpai tufa batu apung dan endapan lahar. Tufa pasiran umumnya melapuk menengah - tinggi berwarna kuning kecoklatan, berukuran pasir halus - kasar. Tufa batu apung berwarna putih kecoklatan, agak rapuh dan mudah lepas. Endapan lahar berwarna abu-abu sampai abu-abu kehitaman terdiri dari batuan beku andesit dan batuapung dengan masa tufa asiran bersifat agak rapuh. Pada kaldera batur formasi geologi terdiri dari formasi geologi Batuan Gunung api Batur yang mengandung aglomerat, lava, dan tufa. 


\section{Kesimpulan}

Penetapan Kaldera Batur sebagai salah satu anggota GGN (Global Geopark Network) 20 september 2012 dilandasi oleh potensi yang dimiliki kawasan batur, seperti warisan geologi Kaldera batur, 15 Desa pendukung yang memiliki batas yang jelas dengan keunikan yang berbeda serta komponen biodiversity batur yang khas. Akan tetapi pasca penetapannya tersebut, banyak terjadi permasalahan dan status nya kini tidak memberikan perubahan berarti bagi keberlanjutan kawasan Batur. Ekonomi masyarakat masih rendah sehingga menimbulkan alih fungsi lahan Geologi sebagai lahan perkebunan. Peningkatan aktivitas galian $\mathrm{C}$ menyebabkan bertambahnya titik-titik bencana longsor. Hal ini tentunya harus menjadi perhatian utama bagi pemerintah, agar bisa mengembalikan ruang spasial kaldera Batur. Konservasi terhadap potensi penyusun geopark merupakan upaya awal yang harus diperhatikan. Bagaimana upaya semua pihak untuk mempertahankan keberlanjutan kawasan geopark namun di sisi lain tetap bisa memberikan kesejahteraan bagi masyarakat Kintamani.

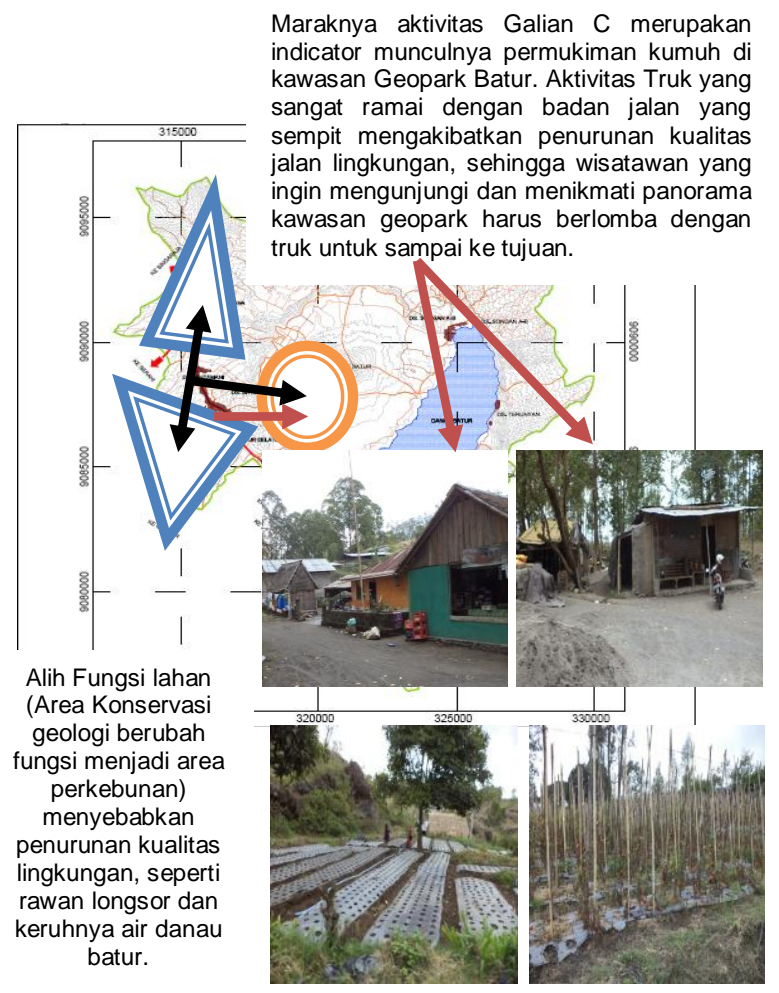

\section{Daftar Pustaka}

Bintarto, R., 1984 . Interaksi Desa-Kota. Jakarta: Ghalia Indonesia.

Haryadi dan Setiawan, 1995. Arsitektur Lingkungan dan Perilaku. Direktorat Jenderal Pendididkan Tinggi, Departemen Pendidikan dan Kebudayaan Republik Indonesia.

Muhadjir, N., 1992. Metodologi Penelitian Kualitatif. Yogyakarta: Tesis, Program Pasca Sarjana, Universitas Gadjah Mada.

Mulyati, A, 1995. Pola Spasial Permukiman di Kampung Kauman Yogyakarta. Yogyakarta: Rake Sarasin.

Soekanto S, 2000. Sosiologi Suatu Pengantar. Jakarta: PT. RajaGrafindo Persada.

Subroto, YW., Setiawan, B.dan Setiadi, 1997. Proses Transformasi Spasial dan Sosio- Kultural Desa-Desa di daerah Pinggiran Kota (Urban Fringe) di Indonesia (Studi kasus Yogyakarta). Yogyakarta: Pusat

https://www.baturglobalgeopark.com/index.p $\mathrm{hp} /$ profil/25/Geodiversity.html 